\title{
GENEALOGI INTELEKTUAL DAN PEMIKIRAN HUKUM ISLAM TUAN GURU H.M. SAID AMIN BIMA (1936-2015)
}

\author{
Oleh: Muhammad Mutawali ${ }^{1}$
}

\begin{abstract}
Abstrak
Kehadiran ulama Bima di Timur Tengah yang diawali dengan munculnya Syekh Abdul Ghani Al-Bimawi yang merupakan salah seorang dari pencetus lahirnya jaringan ulama, membuktikan bahwa keterlibatan ulama Bima di Timur Tengah sangat memengaruhi terbentuknya jaringan ulama Nusantara.
\end{abstract}

Kajian tentang ulama di Timur Nusantara, khususnya di Bima dan sekitarnya sangat jarang, terutama kaitannya dengan jaringan ulama Nusantara pada abad ke-XVIIIXX. Kajian ini diharapkan bukan hanya untuk mengisi kekurangan kajian tersebut, akan tetapi berupaya untuk membuka jalan untuk kajian dan penelitian yang berkelanjutan tentang jaringan ulama Bima di Nusantara. Tulisan ini akan mengkaji salah seorang Tuan Guru yang hidup pada abad XX, yang merupakan generasi akhir dari keterlibatan ulama Bima dalam jaringan ulama Nusantara, yaitu Tuan Guru H.M. Said Amin. Penelitian ini difokuskan pada mata rantai intelektualitasnya sehingga dapat ditemukan simpul keterkaitannya dalam jaringan ulama Nusantara, dan diakhiri dengan beberapa pemikirannya dalam Hukum Islam.

Kata Kunci: Jaringan Ulama Nusantara, Ulama Bima, Tuan Guru, Hukum Islam.

\section{Latar Belakang}

Sejarah terbentuknya jaringan antara penuntut ilmu dari Nusantara dengan ulama-ulama Timur Tengah, khususnya

1 Dosen UIN Mataram, Ketua STIS Al-Ittihad Bima, Mahasiswa Pascasarjana (S3) UIN Jakarta, e-mail: ahmadmutawali69@gmail.com. 
Haramayn, melibatkan proses sejarah yang amat kompleks. ${ }^{2}$ Terbentuknya jaringan ulama-santri adalah merupakan hasil dari proses panjang yang telah dilakukan sejak zaman kolonial Belanda yang mengawasi Islam. Jejak gerakan ulama Nusantara di timur tengah dapat dilacak sejak abad ke-17 M. ${ }^{3}$

Dinamika Islam pada abad ke-17 dan ke-18 adalah jaringan ulama, yang terutama berpusat di Mekah dan Madinah. Posisi penting al-Haramayn, khususnya berkaitan dengan ibadah haji yang mendorong penuntut ilmu dari berbagai wilayah dunia Muslim, khususnya Nusantara datang dan bermukim, yang akhirnya menciptakan semacam jaringan keilmuan yang menghasilkan wacana ilmiah yang unik. Terdapat usaha sadar di antara ulama dalam jaringan untuk membarui dan merevitalisasi ajaran-ajaran Islam dalam tema rekonstruksi sosio-moral masyarakat muslim. ${ }^{4}$

Banyak penuntut ilmu yang terdiri dari anak muda Nusantara yang tinggal menetap beberapa tahun di Mekah dan Madinah untuk memperdalam pengetahuan mereka. Bahkan ada diantaranya menjadi ulama terkemuka dan mengajar di Haramayn. Para ulama ini pada akhirnya turut aktif dalam alam intelektualisme dan spiritualisme di dunia Islam, dan mempengaruhi perubahan watak Islam di Indonesia. ${ }^{5}$

Dengan adanya ritual haji setiap tahun, al-Haramayn menjadi ajang kegiatan rapat akbar kaum Muslimin dari berbagai penjuru dunia. Mekah dan Madinah menjadi pusat intelektual dunia muslim -

2 Azyumardi Azra, Jaringan Ulama Timur Tengah dan Kepulauan Nusantara Abad XVII \& XVIII, (Jakarta: Kencana PrenadaMedia Group, 2013), 1.

${ }^{3}$ Zainul Milal Bizawie, Masterpiece Islam Nusantara: sanad dan jejaring ulama-santri (1830-1945), (Jakarta: Pustaka Compass, 2016), 263-264. Meluasnya jejaring ulama pada fase ini bermula dari dibukanya lahan perkebunn kopi, tebu dan tembakau di beberapa daerah yang meningkatkan taraf kesejahteraan masyarakat. Meningkatnya akumulasi kekayaan masyarakat inilah yang mendorong sebagian mereka untuk mengirimkan anak-anaknya untuk belajar ke timur tengah, pada saat yang sama dibukanya terusan Suez pada tahun 1869 semakin memperlancar arus transportasi ke negara tujuan. Di pihak lain, meningkatnya jamaah haji, disamping meningkatnya santri yang mendalami ilmu di timur tengah, menjadi system komunikasi efektif antara umat islam di Nusantara dengan timur tengah. Sistem komunikasi ini terbangun baik melalui jammah haji atau santri yang belajar di timur tengah. Lihat juga Zamakhsyari Dhofier, Tradisi Pesantren, 67.

${ }^{4}$ Azyumardi Azra, Jaringan......., xxiv.

${ }^{5}$ Zamakhsyari Dhofier, Tradisi Pesantren, (Jakarta: LP3ES, 2011), 67-68. 
ulama, sufi, filosof, penyair, penguasa dan sejarawan muslim bertemu dan saling menukar informasi. Inilah salah satu sebab mengapa ulama dan penuntut ilmu yang mengajar dan belajar di Haramayn pada umumnya memiliki pandangan keagamaan lebih kosmopolitan dibandingkan dengan mereka yang berada di kota-kota Muslim lain. ${ }^{6}$

Tradisi keilmuan di kalangan ulama sepanjang sejarah Islam berkaitan erat dengan lembaga-lembaga sosial keagamaan dan pendidikan seperti masjid, madrasah dan ribath dan bahkan rumah guru. Hal ini khususnya jelas di Haramayn, dimana tradisi keilmuan menciptakan jaringan ulama ekstensif, yang mengatasi batas-batas wilayah dan perbedaan pandangan keagamaan. ${ }^{7}$

Penelitian ini sangat penting mengingat masih minimnya penelitian dan pengkajian tentang ulama-ulama di wilayah timur Nusantara, khususnya di Bima dan sekitarnya, selama ini penelitian tentang tokoh ulama masih berkutat dan berpusat di pulau Sumatera dan Jawa, seperti Kajian pemikiran K.H.M. Hasyim Asy`ari, ${ }^{8}$ Syekh Kholil Bangkalan, dan ulama-ulama Nusantara lainnya. Untuk wilayah Nusa Tenggara Barat, ada beberapa penelitian yang mengkaji tentang pemikiran ulama di Lombok, seperti Tuan Guru Syekh Zainuddin Abdul Madjid ${ }^{9}$, Tuan Guru Soleh Chambali Bengkel, ${ }^{10}$ dan Tuan Guru Abdul Ghafur. ${ }^{11}$

Oleh karena itu, sangat menarik untuk mengkaji jaringan ulama di Bima sepeninggal Syekh Abdul Ghani Al-Bimawi ratusan tahun yang lalu. Penulis memilih Tuan Guru H.M. Said Amin sebagai obyek kajian penelitian ini berdasarkan berbagai pertimbangan, seperti: ketokohan, latar Pendidikan, karya dan pemikiran intelektual serta kontribusinya bagi perkembangan Islam di Bima.

\section{Metode Penelitian}

Penelitian ini bersifat kualitatif, metode ini digunakan dengan alasan: pertama, menyesuaikan metode kualitatif lebih mudah apabila

${ }^{6}$ Azyumardi Azra, Jaringan......., 54.

${ }^{7}$ Azyumardi Azra, Jaringan......, 76.

8 Achmad Muhibbin Zuhri, Pemikiran KH. M. Hasyim Asy`ari Tentang Ahl Al-Sunnah wa Al-Jama`ah, (Surabaya: Khalista, 2010).

${ }^{9}$ Lihat Disertasi DR. Masnun, MA

${ }^{10}$ Lihat Disertasi Adi Fadli, Pemikiran Islam Lokal: Studi Pemikiran TGH. M. Soleh Chambali Bengkel Al-Ampenani, Yogyakarta: UIN Sunan Kalijaga, 2010.

${ }^{11}$ Lihat penelitian Jamaluddin, Keterlibatan Ulama Sasak dalam Jaringan Ulama Periode 1754-1904, Jurnal Al-Qalam volume 22 Nomor 1 Juni 2016. 
berhadapan dengan keadaan jamak, kedua, metode ini menyajikan secara langsung hakikat hubungan antara peneliti dan responden, ketiga, metode ini lebih peka dan lebih menyesuaikan diri dengan banyak penajaman pengaruh terhadap pola-pola nilai yang dihadapi. ${ }^{12}$

Penelitian ini merupakan penelitian Library Research dengan Model Historis Faktual, yaitu meneliti substansi teks berupa pemikiran maupun gagasan tokoh sebagai karya keagamaan sebagaimana yang termuat dalam pemikiran dan karya sang tokoh. Berdasarkan bidang keilmuan, jenis penelitian ini adalah penelitian keagamaan, yaitu pengkajian akademis terhadap agama dan keberagamaan. ${ }^{13}$

Studi ini menggunakan pendekatan sejarah agama, pendekatan ini memandang agama dan keberagamaan sebagai produk sejarah. ${ }^{14}$ Melalui pendekatan ini, penulis melakukan derivasi sebuah fakta dan melakukan rekonstruksi proses genesis: perubahan dan perkembangan. Melalui sejarah dapat dilacak asal mula situasi yang melahirkan pemikiran, pendapat atau sikap seorang tokoh. Melalui sejarah pula dapat diketahui stereotype keberagamaan seseorang atau suatu kelompok dan sikapnya terhadap pihak lain. ${ }^{15}$

Pengumpulan sumber adalah langkah pertama yang dilakukan, yang disebut dengan heuristic. Ini merupakan teknik mencari dan mengumpulkan sumber-sumber sejarah, baik tulisan maupun lisan. Sumber-sumber sejarah terdiri dari sumber atau data primer dan sekunder.

Sumber atau data primer adalah sang tokoh yang menjadi obyek penelitian dengan melakukan wawancara secara mendalam dan semua data berupa naskah-naskah atau manuskrip yang ditulis oleh Tuan Guru H.M. Said Amin, baik yang ditulis ulang dan dicetak maupun naskah asli yang ditulis sendiri. Secara keseluruhan naskah yang akan diteliti sudah terkumpul sebanyak 14 naskah yang sudah dicetak menjadi buku.

12 Lexy J. Moeloeng, Metodologi Penelitian Kualitatif, (Bandung: Rosdakarya, 2012), edisi revisi, 9-10.

${ }^{13}$ Imam Suprayogo dan Tobroni, Metodologi Penelitian Sosial-Agama, (Bandung: Rosdakarya, 2001, 109-110.

15 T. Karim Abdullah, Metodologi Penelitian Agama: Sebuah Pengantar, (Yogyakarta: Tiara Wacana, 1989), 72. 


\section{Biografi Singkat}

Tuan Guru H. M. Said dilahirkan di Desa Tawali Kecamatan Wera Kabupaten Bima pada tanggal 1 Januari 1936, lahir dari pasangan H.M. Amin Hasan dan Hj. Thaifah Sanghaji. Tuan Guru H. M. Said Amin merupakan anak ketiga dari delapan bersaudara. Memulai pendidikan pada tingkat Sekolah Rakyat (SR) pada tahun 1943 di Tawali, juga mendapat didikan orang tua dengan pendidikan dan nilai-nilai keislaman, di desa Tawali sang ayah dikenal sebagai guru ngaji dan rumahnya dijadikan sebagai tempat mengaji bagi anakanak yang ada di seluruh pelosok desa hingga banyak yang menginap dan tinggal (mondok) di rumahnya. Sang ibu yang tidak mengenyam bangku sekolah memimpikan dan bercita-cita agar anaknya Tuan Guru H.M. Said Amin dapat menuntut ilmu di tanah Arab khususnya di Mekah Al-Mukarramah.

Pada tahun 1948, Tuan guru H.M. Said Amin berkesempatan untuk berangkat ke tanah suci untuk menuntut ilmu di tanah para Nabi. Keberangkatannya ke Tanah Arab diantar oleh pamannya yang bernama H.M. Ali dan berangkat bersama jamaah Haji dari Bima yang berjumlah 800 orang dengan menumpang kapal laut yang bernama Tawali, mungkin hanya kebetulan saja nama kapal laut itu sama dengan nama desa asal Tuan Guru H.M. Said Amin, dan menempuh perjalanan laut selama 15 hari.

Setelah tiba di tanah Arab dan melaksanakan ibadah Haji, Tuan Guru H. M. Said Amin tinggal di Mekah bersama dengan orang Bima yang bernama Syekh Yunus (Maryam Qudus), orang asal Ngali Bima yang sudah lama mukim di Mekah. ${ }^{16}$

\section{Genealogi Intelektual Tuan Guru H.M. Said Amin}

Tahun 1949 dijadikan sebagai titik awal perjalanan panjang dan pengembaraan menuntut ilmu di tanah kelahiran Nabi junjungan kita Muhammad SAW, Tuan Guru H. M. Said Amin diterima sebagai siswa di Madrasah Ibtidaiyah Darul Ulum Mekah, selama belajar di Darul Ulum bersama dengan teman-teman yang berasal dari Malaysia, Singapura, Philipina dan Negara Asia lainnya, Tuan Guru H. M. Said Amin selalu berprestasi dan mendapat juara paling rendah juara III di kelasnya. Madrasah Ibtidaiyah Darul Ulum pada waktu

${ }^{16}$ Hasil wawancara langsung penulis dengan Tuan Guru H. M. Said Amin di kediaman beliau di kampung Saleko Pada tahun 2012. Biografi beliau dapat dilihat juga dalam buku-buku karyanya. 
itu dikepalai oleh Syekh Mansyur dari Palembang, Syekh Yasin Padang menjabat Wakil kepala sekolah, sedangkan para guru berasal dari hampir seluruh Negara di Asia dan salah satunya adalah Syekh Umar yang berasal dari Sumbawa yang sudah lama mukim di sana. Pada saat kelas 5, Tuan Guru H. M. Said Amin mendapat juara 1 dan berhak menjadi ketua kelas, karena sudah menjadi aturan bahwa yang berhak menjadi ketua kelas adalah yang mendapat juara 1 kelas.

Pada tahun 1952, Tuan Guru H. M. Said Amin melanjutkan studi pada MTs Al-Falah Mekah tingkat Kafa`ah dan pernah meraih juara 5 kelas padahal didominasi oleh orang Arab yang kebanyakan anak-anak dari para pejabat tinggi kerajaan Saudi Arabia. MTs AlFalah dikepalai oleh Syekh Sayid Ishak Ajuz yang menjabat juga sebagai anggota parlemen Saudi Arabia, Syekh Muhammad Abdul Muhsin Ridwan menjabat sebagai Wakil Kepala Madrasah. Selama menuntut ilmu di MTs Al-Falah, Tuan Guru H.M.Said Amin selalu dibimbing oleh tokoh-tokoh besar yang sangat memengaruhi keilmuan dan pemikirannya, di antara yang paling berkesan adalah pernah dibimbing langsung oleh Syekh Muhammad Al-Arabi AlTijani, seorang Ulama yang berasal dari Aljazair dan mengajar Tafsir yang dikenal sebagai ahli Tafsir terkemuka di Tanah Arab. Dibimbing juga oleh Syekh Muhammad Nursyef berasal dari Bahrain yang dikenal juga sebagai ulama besar di Arab, khusus untuk ilmu Hadis dan Hadis, Tuan Guru H. M. Said Amin langsung dibimbing oleh ulama Hadis terbesar di Arab bahkan di seluruh penjuru dunia waktu itu yang bernama Syekh Alwi Abbas Al-Maliki, bidang Fiqh diajar oleh Syekh Muhammad An`am dari Yaman, bidang Tauhid dibimbing oleh Syekh Muhammad Hasan As-Sanari dari Saudi Arabia, guru sastra dan bahasa Arab yaitu Syekh Musthafa Turayyah Saraf, Bahasa Inggeris oleh Ust. Abdul Aziz dari Mesir, Bahasa Perancis dibimbing oleh Ust. Zaki Awad, guru social oleh Ust. Ismail Shabri dan ilmu Bumi oleh Ust. Taufik.

Tahun 1954, Tuan Guru H.M. Said Amin melanjutkan studi pada Madrasah Aliyah tingkat Taujihi al-Falah Mekah, selama di MA Al-Falah selalu mendapat prestasi sampai juara 3 kelas dan selalu mengikuti kegiatan-kegiatan ilmiah, diskusi dan debat antar siswa. Pernah satu kali mengikuti kegiatan diskusi dan debat antar siswa dengan tema Ahlu Ra'yi wa Ahlu Al-Hadis dan menjadi pendukung Ahlu Al-Hadis dengan karya ilmiah yang berjudul Idza takallamal Ka bah fa madza taquulu? (Jika Ka`bah dapat berkata, apa yang dikatakannya?. Dari hasil penilaian debat dan karya ilmiah tersebut 
Tuan Guru H. M. Said Amin mendapat apresiasi dari pimpinan Madrasah. ${ }^{17}$

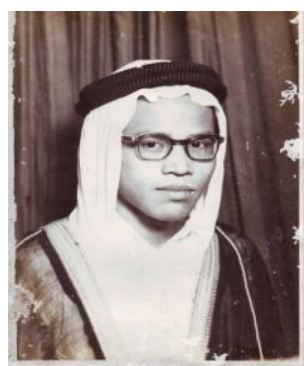

Tuan Guru H.M. Said Amin ketika menjadi siswa di MA Al-Falah Mekah

Pada saat Ujian Negara tingkat Madrasah Aliyah yang diselenggarakan oleh pemerintah Saudi Arabia, Tuan Guru H.M.Said Amin mendapat prestasi juara 2 dari 60 orang yang ikut ujian Negara tahap I. Pada tahun 1956 setelah lulus pada Madrasah Aliyah, diutus oleh lembaga untuk mendalami Bahasa Inggeris pada Universitas Iskandaria di Mesir, akan tetapi dibatalkan karena bukan warga Negara Saudi Arabia. Pada tahun yang sama pula diangkat sebagai guru Hadis pada Madrasah Ibtidaiyah Al-Falah Mekah selama 1 tahun, pada tahun 1957 akan melanjutkan studi pada perguruan tinggi, akan tetapi nasib berkata lain, Tuan Guru H. M. Said Amin dijemput oleh ibunya untuk pulang kampung atas persetujuan Syekh Alwi AlMaliki bersama dengan 60 orang warga Negara Indonesia yang lama mukim di Mekah.

Guru Hadis yang paling memengaruhi dan dekat dengannya adalah Ulama Hadis yang bernama Syekh Yasin bin Isa Al-Fadany alMakky dan telah mendapatkan ijazah dari beliau sebagai Perawi Hadis Musalsal yang bersambung sanadnya sampai kepada Nabi Muhammad SAW. Dengan mengantongi Ijazah tersebut,Tuan Guru H. M. Said Amin mendapat hak dan izin untuk meriwayatkan HadisHadis Nabi dari seluruh Kitab-kitab Hadis yang Mu`tabarah seperti

${ }^{17}$ Hasil wawancara langsung penulis dengan Tuan Guru H. M. Said Amin di kediaman beliau di kampung Saleko Pada tahun 2012. Biografi beliau dapat dilihat juga dalam buku-buku karyanya. 
kitab Shahih Bukhari, Shahih Muslim, Sunan Abi Daud, Sunan Tirmizi, Sunan An-Nasa I dan lain-lain. ${ }^{18}$

\section{Karir dan Rihlah Dakwah}

Sepulang dari Mekah dan tiba di Bima, Tuan Guru H. M. Said Amin diangkat sebagai guru PGAP Bima sampai tahun 1965. Tahun 1965-1967 diangkat sebagai guru PGA M. Salahuddin Bima. Pernah juga menjadi anggota DPRGR Kab. Bima untuk mewakili golongan Islam pada periode tahun 1966-1971. Tahun 1976-1984 diangkat menjadi guru PGAN Bima. Kemudian pada tahun 1967 mulai mendirikan dan menjadi kepala MAAIN Saleko Bima (sekarang MAN I Kota Bima) sampai tahun 1976. Pada tahun 1984 diangkat menjadi Hakim Pengadilan Agama Bima dan pensiun pada tahun 1996.

Pada tahun 1979, Tuan Guru H. M. Said Amin diundang khusus untuk mengikuti Pendidikan dan Pelatihan Imam, Khatib dan Da i tingkat akademisi yang diadakan oleh Dewan Tertinggi Masjid se-dunia di Rabithah Alam Al-Islami di Mekah selama 3 bulan. Selama diklat, langsung dibimbing oleh para ulama besar di antaranya Syekh Ali Tantawi, Syekh Muhammad Al-Ghazali dan Syekh Muhammad Qutub dalam bidang Dakwah, Syekh Sayid Sabiq pada bidang Fiqh dan Qadha, Syekh Dr. Ahmad Umar Hasyim pada bidang Hadis, Dr. Muhammad Abu Nur Al-Hadidi pada bidang Tafsir, Dr. Mujahid As-Sawwaf dalam bidang Aliran dan aqidah, Dr. Syalabi pada bidang Bahasa Arab, Dr. Ammarah dalam bidang pidato dan ceramah, Dr. Assyal pada bidang waris, Syekh Ahmad Al-Huwaili dan Syekh Sulaiman Albalawi dalam bidang Al-Qur`an dan Tajwid.

Setelah mengikuti Diklat yang diikuti sebanyak 50 orang, 5 orang diantaranya berasal dari Indonesia, seluruh peserta ditugaskan untuk menjadi Imam dan Da i di seluruh penjuru dunia, Tuan Guru H. M. Said Amin mendapat tugas dakwah di Malaysia akan tetapi dibatalkan karena sudah berstatus sebagai Pegawai Negeri sipil dan akhirnya ditugaskan dan kembali ke Bima.

Setibanya di Bima, tugas sebagai Da`i mulai dilaksanakan dan berdakwah sampai ke seluruh pelosok daerah Bima dan bergabung dengan organisasi Ittihadul Muballighin dan menjadi ketua wilayah

${ }^{18}$ Hasil wawancara langsung penulis dengan Tuan Guru H. M. Said Amin di kediaman beliau di kampung Saleko Pada tahun 2012. Biografi beliau dapat dilihat juga dalam buku-buku karyanya. 
Nusa Tenggara Barat yang berkantor di Bima. Ittihadul Muballighin adalah organisasi persatuan para muballigh yang memfokuskan kegiatannya pada bidang pendidikan dan dakwah yang memiliki cabang di setiap kecamatan di seluruh Kabupaten Bima. Melalui organisasi ini, Tuan Guru H. M. Said Amin melanglang buana untuk berdakwah menyampaikan dan membagi ilmu yang diperoleh selama menuntut ilmu di Mekah. ${ }^{19}$

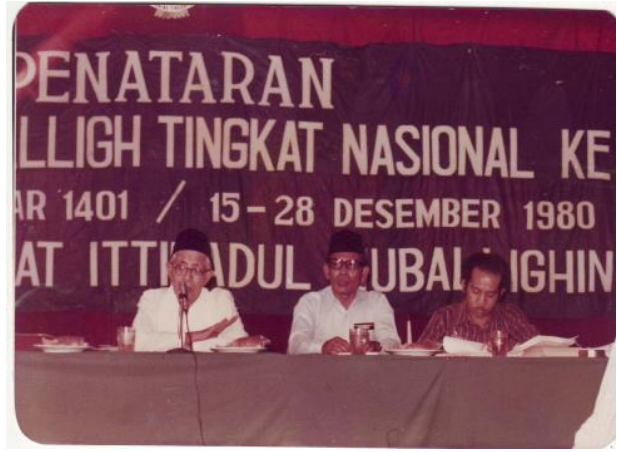

Tuan Guru H.M. Said Amin (tengah) ketika memimpin rapat dalam Pelatihan Da`i Tingkat Nasional Ittihadul Muballighin Pada tahun 1980 dan M. Natsir (kiri) sebagai narasumber.

Pengalaman organisasi Tuan Guru H. M. Said Amin dimulai ketika menuntut ilmu di Mekah, pernah menjadi sekretaris Ikatan Pelajar Bima-Dompu di Mekah Saudi Arabia pada tahun 1951-1957, tahun 1966-1980 menjadi Ketua III NU cabang Bima dan pernah menjadi pengurus Yayasan M. salahuddin Bima, mulai tahun 1968 menjadi anggota pengurus Yayasan Islam Bima sampai 2015, pada tahun 1968, menjadi ketua presidium Musyawarah Alim Ulama Kab. Bima dan anggota panitia pendirian Fakultas Syari ah IAIN Sunan Ampel Cabang Bima, pada tahun 1971 mendirikan Fakultas Tarbiyah Sunan Giri yang sekarang menjadi STIT Sunan Giri Bima, dari tahun 1973-2007 menjadi ketua Yayasan Darul Tarbiyah Bima, tahun 1980 sampai 2015 menjabat sebagai ketua Yayasan Ittihadul Muballighin Bima, tahun 1985 beliau mendirikan dan menjadi Ketua Yayasan Pendidikan dan Dakwah Al-Ittihad Bima yang meliputi Pondok Pesantren Al-Amin Bima, STIS Al-Ittihad Bima, MA Plus Al-Ittihad Kota Bima, MTs La Hami Kab. Bima dan RA Al-Amin Kota Bima.

${ }^{19}$ Hasil wawancara langsung penulis dengan Tuan Guru H. M. Said Amin di kediaman beliau di kampung Saleko Pada tahun 2012. Biografi beliau dapat dilihat juga dalam buku-buku karyanya. 
Pada tahun 1990, Tuan Guru H. M. Said Amin diangkat sebagai ketua Majelis Ulama Indonesia (MUI) Kab. Bima. Pengangkatannya sebagai ketua MUI Kab. Bima adalah berdasarkan hasil keputusan Musyawarah Daerah dan penunjukan langsung dari Ketua MUI sebelumnya yang dijabat oleh Tuan Imam K.H. Abdurrahman Idris. Tugas sebagai Ketua MUI diemban dan dilaksanakan dengan penuh amanah dan tanggung jawab selama 21 tahun, dan mengakhiri masa jabatannya pada tahun 2011.

Selama 21 tahun menjabat sebagai ketua MUI Kab. Bima, beliau telah melakukan perjalanan dakwah sampai ke seluruh pelosok tanah Bima, untuk menyiarkan keagungan agama Islam dan menjaga kemurnian risalah Islam.

Pada tahun 2001 sampai 2015 menjadi anggota forum komunikasi lembaga dakwah kab. Bima, tahun 1997 sampai 2015 menjadi anggota pesasihat BAZDA Kab. Bima, dan tahun 2004 sampai 2015 menjadi anggota Yayasan At-Taqwa Internasional yang berpusat di London Inggeris. ${ }^{20}$

\section{Karya-karya Intelektual}

Selama hidupnya Tuan Guru H. M. Said Amin mengabdikan dirinya untuk berdakwah dan memperjuangkan Islam yang bermanhaj Salaf Ash-Shalih yang beraliran Ahlu Sunnah wal Jamaah. Dalam berdakwah dan berjuang untuk mempertahankan kemurnian ajaran Islam yang bersumber dari Al-Quran dan Sunnah Nabi, Tuan guru H. M. Said Amin tidak hanya berdakwah dengan menggunakan media lisannya saja atau Da wah Bi Lisan, akan tetapi untuk menyampaikan dakwah dan pemikirannya serta pemahaman keislamannya, beliau telah banyak menghasilkan karya tulis dalam bentuk buku-buku yang telah beredar bukan hanya pada tingkat lokal akan tetapi hasil karyanya telah beredar secara Nasional dan dijadikan sebagai referensi dan buku rujukan bagi mahasiswa dan dosen di Perguruan Tinggi Islam.

Di antara buku-buku karya tulisnya sebagai berikut:

1. Sifat Shalat Rasulullah (diterbitkan oleh Sunan Ampel Press IAIN Surabaya kerjasama dengan IT Press STIS Al-Ittihad Bima, tahun 2012),

2. Sejarah timbulnya perpecahan di kalangan umat islam

${ }^{20}$ Hasil wawancara langsung penulis dengan Tuan Guru H. M. Said Amin di kediaman beliau di kampung Saleko Pada tahun 2012. Biografi beliau dapat dilihat juga dalam buku-buku karyanya. 
3. Menuju Pelaksanaan Syari at Islam, tahun 2002.

4. Peristiwa Ghadir khum melahirkan kebohongan Syi ah ahlul bait, tahun 2001.

5. Konspirasi Internasional dan masa depan agama-agama (diterbitkan oleh Penamadani Press, Jakarta)

6. Mewaspadai pemurtadan umat Islam, tahun 2006.

7. Adam Abul Basyar (koreksi terhadap buku Ternyata Adam dilahirkan), (diterbitkan oleh IT Press STIS Al-Ittihad Bima, 2007)

8. Manusia Dan Ibadah haji (IT Press STIS Al-Ittihad Bima tahun 2008)

9. Ajaran Agama Masehi setelah kenaikan Isa Al-masih (IT Press STIS Al-Ittihad Bima tahun 2012)

10. Siksa dan Nikmat Kubur (IT Press STIS Al-Ittihad Bima tahun 2013)

11. Menggugat Aliran-Aliran Teologi dalam Islam (diterbitkan oleh IT Press STIS Al-Ittihad Bima, tahun 2013)

12. Ar-Risalah Al-Aminiyah, Berislam bersama TGH. M. Said Amin, (Pengantar Ilmu Hadis dan Ilmu Fiqh), (IT Press STIS AlIttihad Bima, tahun 2013).

13. Ar-Risalah Al-Aminiyah, Berislam menurut Al-Qur`an dan AsSunnah, seri Aliran-aliran ilmu kalam dan pemimpin yang menyesatkan umat, (IT Press STIS Al-Ittihad Bima tahun 2014).

14. Ar-Risalah Al-Aminiyah, Berislam menurut Al-Qur`an dan AsSunnah, seri Manusia dan Ibadah Haji, (IT Press STIS Al-Ittihad Bima tahun 2014).

15. Ar-Risalah Al-Aminiyah, Berislam menurut Al-Qur`an dan AsSunnah, seri Siksa dan Nikmat Kubur, (IT Press STIS Al-Ittihad Bima tahun 2014).

16. Ar-Risalah Al-Aminiyah, Berislam menurut Al-Qur`an dan AsSunnah, seri Perjalanan Hidup Manusia dari alam arwah sampai alam Baqa', (IT Press STIS Al-Ittihad Bima tahun 2014).

17. Kitab Wird al-Ittihad, yang berisi kumpulan do`a-do`a dan wirid sebagai amalan bagi Jamaa`ah Al-Ittihad yang beliau pimpin. ${ }^{21}$

21 Buku-buku yang beliau tulis merupakan respon dan jawaban dari banyaknya pertanyaan masyarakat, juga dari peristiwa dan fenomena yang terjadi pada masyarakat Bima. 


\section{Keterlibatan Ulama Bima dalam Jaringan Ulama Nusantara}

Bagi umat Muslim, termasuk di Indonesia, ulama memainkan peran yang penting, tidak saja dalam hal keagamaan, tetapi juga mencakup bidang-bidang yang lain, seperti sosial, politik dan budaya. Bahkan Clifford Geertz sendiri menyebut ulama/Kiyai sebagai pialang budaya (cultural broker). ${ }^{22}$ Pada bidang Pendidikan, sejumlah Ulama Nusantara mendirikan madrasah di Mekah dan Madinah, seperti Madrasah Darul Ulum ad-Diniyah, tercatat sekitar 5.000 mahasiswa Indonesia menimba ilmu di Haramayn. ${ }^{23}$ Tokoh-tokoh ulama seperti Hamzah Fansuri, ${ }^{24}$ Syamsuddin as-Sumatrani, ${ }^{25}$ Nuruddin ar-Raniri ${ }^{26}$ dan Abdurrauf as-Singkilii ${ }^{27}$ yang dapat mengantarkan keempat sarjana dan budayawan Islam tersebut mendampingi para Sultan untuk turut serta mengatur pemerintahan.

Tokoh-tokoh ulama seperti Syekh Abdul Ghani al-Bimawi, ${ }^{28}$ Syekh Nawawi al-Bantani, dan Syekh Ahmad Khatib Minangkabau

22 Agus Iswanto, Sejarah intelektual Ulama Nusantara: Reformulasi Tradisi di Tengah Perubahan, dalam Jurnal Lektur keagamaan, Vol. 11, No. 2 tahun 2013, 456.

${ }^{23}$ Zamakhsyari Dhofier, Tradisi Pesantren, (Jakarta: LP3ES, 2011), 69.

${ }^{24}$ Syekh Hamzah Fansuri merupakan salah satu ulama hebat dan terkenal dari segi pemikiran dan karyanya, yang telah mengilhami perkembangan Islam di Nusantara, khususnya di daerah tempat tinggalnya, Aceh. Bahkan hingga kini, pemikirannya menjadi objek kajian para ilmuwan dan juga sastrawan dari dalam dan luar negeri.

${ }^{25}$ Nama lengkapnya adalah Syekh Syamsuddin as-Sumatrani ibn Abdullah as-Sumatrani, beliau pernah menjadi ulamaa terkenal pada masa kesultanaan Aceh, setelah Syekh Hamzah Fansuri, beliau adalah murid Syekh Hamzah fansuri, pada masa kepemimpinan Sultan Iskandar Muda (1607-1636 M).

${ }^{26}$ Nama lengkapnya adalah Nuruddin Muhammad ibn Ali Hamid ar-Raniri, nama belakangnya ar-Raniri, kemungkinan besar merupakan julukan berdasarkan tempat kelahirannya yakni Ranir, sebuah kota pelabuhan berdekatan dengan Gujarat India, lahir sekitar abad ke-16.

${ }^{27}$ Nama lengkapnya adalah Aminuddin Abdul Rauf bin Ali al-Jawl Tsumal Fansuri as-Singkil, dilahirkan pada tahun 1593 M (1001 H) dari keluarga ulama.

${ }^{28} \mathrm{Nama}$ lengkapnya adalah Syekh Abdul Ghani Bima bin Subuh bin Ismail bin Abdul Karim al-Bagdadi (La Bogdadi) yang lahir di tahun 1780 M di Bima NTB, ayahnya Syekh Subuh diangkat oleh Sultan Bima Alauddin Muhammad Syah (17311743) di Kesultanan Bima. Di Mekkah, Syekh Abdul Ghani menjadi salah satu imam besar, di antara murid-muridnya adalah Syekh Nawawi Banten, Syekh Ahmad Khatib as-Sambasi, Syekh Kholil Bangkalan. Beliau mendapat gelar Sayyid Ulamail Hijaz dari negeri Timur dan beliau merupakan penyambung mata rantaai jaringan ulama Nusantara abad ke-19 dengaan timur tengah. 
yang dapat leluasa belajar ke Mekah dan naik ke puncak sebagai guru besar dan Imam Masjidil Haram. Satu hal yang cukup menarik dari perkembangan ini adalah bahwa para pelajar dari berbagai daerah yang melanjutkan pelajaran di Mekah biasanya baru dianggap menyempurnakan pelajaran mereka setelah memperoleh bimbingan terakhir dari ulama kenamaan dari Nusantara tersebut. ${ }^{29}$

Nama-nama ulama di Nusantara banyak sekali tetapi ada beberapa yang terdapat dalam literatur Arab atau tarajim (Historiografi) Arab sejak abad ke-18 sampai masa kontemporer. Diantaranya adalah Sayyid `Abd al-Rahman `Abd al-Shamad alPalimbani (dari Palembang), Syekh Mahfudz al-Termasi (dari Termas Jawa Timur), Syekh Nawawi al-Bantani (dari Banten), sampai pada Syekh Muhammad Yasin ibn Isa al-Padani (dari Padang). ${ }^{30}$

Para Ulama di atas hampir semuanya merupakan penulispenulis yang produktif, dari tangan mereka muncul puluhan karya yang berjilid-jilid sampai risalah-risalah pendek. Karya-karya tersebut ditulis dalam Bahasa Arab, Melayu, Jawa atau Bahasa lokal lainnya. Sebagian kecil karya-karya Ulama tersebut diterbitkan di beberapa negara seperti Istanbul, Kairo, Beirut, Bombay, dan Singapura. Saat ini, kebanyakan karya-karya tersebut dicetak ulang di Nusantara. ${ }^{31}$

Memasuki paruh kedua abad ke-19 dan awal abad ke-20, semakin banyak ulama tanah Jawa (bilad Jawa ${ }^{32}$, Nusantara) yang menuntut ilmu di tanah suci. Informasi tentang biografi mereka lebih banyak dan tercatat dengan cukup detail dalam kitab-kitab sanad dan

${ }^{29}$ Zamakhsyari Dhofier, Tradisi Pesantren, (Jakarta: LP3ES, 2011), 66-67.

${ }^{30}$ M. Khoiril Anwar, Peran Ulama di Nusantara dalam Mewujudkan Harmonisasi Umat Beragama, dalam Jurnal Fikrah, vol. 4 Nomor 1, tahun 2016, 87. Lihat juga Zainul Milal Bizawie, Masterpiece Islam Nusantara, 264-265.

31 Nor Huda, Islam Nusantara: Sejarah Sosial Intelektual Islam di Indonesia, (Yogyakarta: ar-Ruzz Media, 2013), 191. Kitab-kitab tersebut di antaranya adalah Sirath al-Mustaqim (fiqh dan ibadah) karya ar-Raniri, Terjuman al-Mustafid (Tafsir) dan Mir'at al Thullab (figh dan mu'amalah) karya 'Abd rauf asSingkili, Sabil al-Muhtadin (fiqh) karya Muhammad Arsyad al-Banjari, Minhaj Zawi al-Nazar (hadis) karya Abdullah Mahfudz al-Termasi, Majmu 'at al-Syari'ah, Faid alRahman (fiqh dan Tafsir) karya Muhammad Shalih bin Umar al-Sumarani (Kiyai Sholeh darat Semarang).

${ }^{32}$ Bilad Jawa mengandaikan satu komunitas muslim dari Nusantara yang sedang menuntut ilmu di Mekkah dan juga sebagai identitas kultural-keagamaan muslim Nusantara. Lihat Achmad Muhibbin Zuhri, Pemikiran K.H.M. hasyim Asy 'ari tentang Ahl al-Sunnah wa al-jama`ah, 92-93. 
buku biografi Arab. Banyak di antara mereka telah mendapat ijazah (sertifikasi) mengajar di Masjidil Haram. Hal tersebut menjadikan mereka sebagai penerus jejaring ulama Nusantara yang telah dirintis oleh para ulama nusantara sebelumnya. ${ }^{33}$

Ulama-ulama Nusantara di Mekah telah meletakkan dasar bagi terciptanya jejaring ulama di Nusantara, yang kemudian menjadi sebuah komunitas ulama. Selain membangun pesantren, ulama memiliki hubungan kuat dalam bidang spiritual dan intelektual. Mereka mengidentifikasi diri sebagai bagian dari komunitas ulama yang memiliki sanad bersambung kepada ulama-ulama Nusantara di Mekah. ${ }^{34}$

Maka, sangatlah wajar kalau perkembangan Islam di Nusantara sangat dipengaruhi oleh perkembangan Islam di Haramayn. Setelah kembali ke tanah air, mereka berusaha untuk menyelenggarakan Pendidikan sebagaimana yang diketahui dan dipelajari di tanah suci. ${ }^{35}$ Peran mereka para alumni Haramayn menjadi transmitter utama tradisi intelektual-keagamaan tradisi Islam dari pusat-pusat keilmuan Islam di Timur Tengah ke Nusantara. ${ }^{36}$

Kebanyakan dari ulama dalam jaringan memiliki komitmen kepada pembaruan Islam. Gejolak dan dinamika pemikiran yang muncul dari hubungan dan kontak yang begitu intens melalui jaringan ulama memunculkan efek revitalisasi Islam dalam kehidupan pribadi dan kemasyarakatan kebanyakan kaum muslim melayu-Indonesia. ${ }^{37}$

Di Timur Nusantara, di pulau Sumbawa yang meliputi Sumbawa, Dompu dan Bima dikenal sebagai pusat pesantren, sejak dulu Sumbawa menjadi simpul utama jejaring ulama di bagian timur. Sebut saja Syekh Abdul Ghani al-Bimawi yang menjadi guru Syekh Nawawi al-Bantani, Syekh Zainuddin Sumbawi ${ }^{38}$ dan ulama-ulama

${ }^{33}$ Zainul Milal Bizawie, Masterpiece Islam Nusantara: sanad dan jejaring ulama-santri (1830-1945), (Jakarta: Pustaka Compass, 2016), 263.

${ }^{34}$ Zainul Milal Bizawie, Masterpiece......, 268

35 Jamaluddin, Keterlibatan Ulama Sasak dalam Jaringan Ulama periode 1754-1904, dalam Jurnal al-Qalam, vol 22 Nomor 1 juni 2016, 52.

${ }^{36}$ Azyumardi Azra, Jaringan........,xxvi-xxvii.

${ }^{37}$ Azyumardi Azra, Jaringan........, xvii-xviii

${ }^{38}$ Syekh Zainuddin Sumbawi adalah khalifah tarekat Qadiriyah, yaitu tarekat yang dinisbatkan kepada Syekh Abdul Qadir al-Jilani. la menerima tarekat Qadiriyah dari Syekh Muhammad Mukrim, mufti Hamad dari negeri Syam. Sanadnya dalam bidang hadis Muslim diterima dari Syekh Nawawi al-Bantani dan hadis Bukhari dari Syekh Abdul Karim al-Bantani. 
lainnya di Nusantara. Ulama dan pesantren di Nusa Tenggara tersebut memiliki hubungan yang sangat dekat dan menjadi simpul utama jejaring ulama terkoneksi dengan jejaring ulama di Jawa, Bali dan Sulawesi. ${ }^{39}$

Pada abad ke-19 dan abad ke-20, Kesultanan Bima memfasilitasi bagi warga masyarakatnya yang ingin belajar agama di pulau Jawa dan menuntut ilmu di Timur Tengah khususnya di Mekah dan Madinah, sebagai bentuk perhatian Sultan bagi perkembangan keilmuan dan Pendidikan Islam di Bima. Sehingga ketika mereka pulang dari menimba ilmu di Timur Tengah akan dijadikan sebagai guru agama yang akan mengajar dan mengabdikan dirinya pada lembaga Pendidikan Islam yang didirikan oleh pihak Kesultanan, seperti Madrasah Darul Ulum di Raba Bima. ${ }^{40}$

Tidak banyak ulama Bima yang menuntut ilmu di AlHaramayn dan mengajar di Mekah serta menjadi perawi hadis musalsal, ia adalah Tuan Guru ${ }^{41}$ H.M. Said Amin, ${ }^{42}$ murid langsung Syekh Yasin bin Isa al-Fadani al-Makky dan mendapatkan Ijazah Sanad hadis darinya.

Oleh Karena itu, untuk melacak genealogi intelektual dan pemikiran Tuan Guru H.M Said Amin, menjadi sangat terkait, dan tentu saja harus kembali pada mata rantai sanad (silsilah) intelektualitas tokoh-tokoh Ulama yang sangat memengaruhi perkembangan jaringan ulama Nusantara di Timur Tengah pada abad ke 18 sampai abad ke 20.

${ }^{39}$ Zainul Milal Bizawie, Masterpiece......., 457.

40 Hal ini menjadi salah satu faktor yang menyebabkan kurang berkembangnya Pondok Pesantren di wilayah Bima, Karena setiap alumni Haramayn yang pulang menimba ilmu, secara otomatis diangkat dan dijadikan sebagai guru agama di sekolah dan madrasah yang didirikan oleh pihak Kesultanan.

${ }^{41}$ Tuan guru adalah sebutan bagi seseorang yang memiliki pengetahuan agama yang tinggi yang diberikan oleh masyarakat sebagai wujud dari pengakuan mereka terhadap kelebihan-kelebihan yang dimiliki seseorang. Gelar Tuan guru juga diberikan kepada tokoh berpengaruh yang pernah menimba ilmu di Timur Tengah.

${ }^{42}$ Beliau lahir di Bima pada tanggal 1 Januari 1936 dan meninggal 30 April 2015, pergi menimba ilmu di Mekkah pada usia 12 tahun tepatnya pada tahun 1948 di Madrasah Dar al-Ulum Mekkah dan berada dalam bimbingan Syekh Yasin al-Padani. 
Berikut diagram genealogi Intelektual Tuan Guru H.M. Said Amin

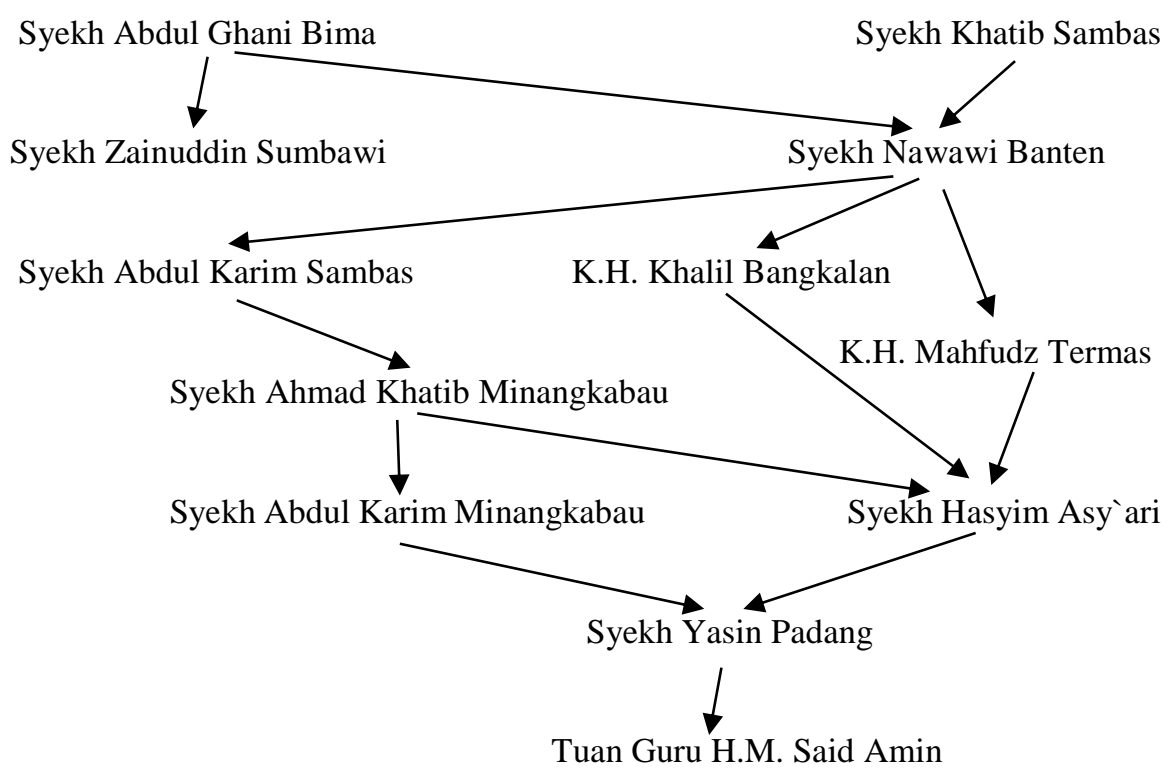

(diolah dari beberapa sumber dan dari sanad Hadis yang bersumber dari Syekh Yasin Padang)

Berdasarkan fakta tersebut di atas, jelas terlihat bahwa beliau pernah berguru pada ulama-ulama paling berpengaruh di Timur Tengah pada abad ke XX seperti Syekh Alwi Abbas Al-Maliki, Syekh Muhammad Al-Arabi Al-Tijani, Syekh Ali Tantawi, Syekh Muhammad Al-Ghazali, Syekh Muhammad Qutub dan Syekh Sayid Sabiq serta Ulama Nusantara di Timur Tengah yang termasuk dalam jejaring ulama Nusantara di Timur Tengah seperti Syekh Yasin Padang yang terhubung dengan jaringan ulama Nusantara antara Abad XVIII dan XIX, seperti Syekh Abdul Karim Minangkabau, Syekh Ahmad Khatib, Syekh Hasyim Asy`ari, Syekh Mahfudz Termas, Syekh Kholil Bangkalan, Syekh Abdul Karim Sambas, sampai kepada Syekh Nawawi Al-Bantani dan Syekh Abdul Ghani Al-Bimawi. Pemikiran dan keilmuan yang didapatkannya dari mereka, sangat memengaruhi pemikiran dan intelektualitasnya, sehingga terlihat corak dan karakteristik yang khas dalam pemikirannya. Sehingga, tidak ragu lagi bahwa pendidikannya sangat lengkap dan komprehensif. Beliau memiliki pengetahuan yang mumpuni untuk membuatnya tampil sebagai ulama pelanjut sanad 
keilmuan dalam jaringan ulama Nusantara dari Bima pasca Syekh Abdul Ghani Al-Bimawi.

Tuan Guru H.M. Said Amin merupakan salah seorang ulama produktif di antara para ulama di Bima. Pemikiran keislamannya dituangkan dalam karya-karyanya, lebih dari 20 karya yang beliau tulis, sebagian besar telah dicetak menjadi buku, yang membahas berbagai kajian keislaman, seperti: Fiqh, hadis, aqidah akhlak dan tasawuf, yang merupakan bentuk tanggung jawabnya sebagai seorang ulama dalam memberikan pencerahan kepada masyarakatnya, sehingga dengan keilmuan dan aktifitas dakwahnya, beliau telah memenuhi tiga unsur fundamental dakwah, yaitu $D a^{`}$ wah bi al lisan, Da`wah bi al hal dan Da`wah bi al qalam. Apa yang dilakukannya, tidak banyak dilakukan oleh ulama-ulama lainya, sehingga beliau diberi tanggung jawab untuk membimbing masyarakatnya, hal ini dapat kita lihat dari rihlah dakwahnya selama memimpin lembaga Majelis Ulama Indonesia Kabupaten Bima selama 21 Tahun.

Satu kelebihannya dibandingkan dengan ulama Bima yang lain, yaitu meriwayatkan hadis, dikarenakan beliau mendapatkan ijazah Sanad Hadis dari Gurunya Syekh Yasin Padang, sehingga berhak untuk meriwayatkan hadis dari kitab-kitab hadis Mu tabarah yang bersambung sanadnya sampai Rasulullah. Syekh Yasin Padang yang bergelar Al-Musnid Dunya (ulama ahli musnad dunia), dikenal memiliki keahlian dalam ilmu periwayatan hadis. Sehingga banyak para ulama dunia berbondong-bondong untuk mendapat ijazah sanad hadis darinya, seperti Habib Segaf bin Muhammad Assegaf, salah seorang ulama dan waliyullah dari Tarim Hadramaut. ${ }^{43}$

Dalam tradisi belajar mengajar di kalangan umat Islam, sanad ilmu menjadi salah satu unsur utama, disiplin ilmu keislaman apapun, sanadnya akan bermuara kepada Nabi Muhammad SAW. Sanad merupakan mata rantai transmisi yang berkesinambungan sampai Rasulullah. Begitu pentingnya sebuah sanad, sehingga Ibn Abdil Bar meriwayatkan dari Imam Al-Auza i bahwasanya ia berkata: tidak hilang ilmu agama melainkan dengan hilangnya sanad, Imam Syafì i juga berkata: Tiada ilmu tanpa sanad. ${ }^{44}$

${ }^{43}$ Zainul Milal Bizawie, Master Piece 252. Lihat Rizem Aizid, Biografi Ulama Nusantara, (Yogyakarta: Diva Press, 2016), 173. Lihat juga Amirul Ulum, Syaikh Yasin ibn Isa Al-Fadani: Sang Musnid Dunia dari Nusantara, (Yogyakarta: Global Press, 2016.

${ }^{44}$ Zainul Milal Bizawie, Master Piece. 299. 
Sebagaimana pendapat JO.Voll yang dikutip oleh Azyumardi Azra bahwa Sarana terpenting yang membuat hubungan sesama jaringan relative solid adalah Isnad hadis, karena memainkan peranan yang krusial dalam menghubungkan ulama yang terlibat dalam jaringan, yang berpusat di Haramayn. ${ }^{45}$

Tuan Guru H.M Said Amin juga pernah diangkat untuk menjadi guru hadis di almamaternya, Madrasah Al-Falah di Mekah. Penghormatan untuk menempati posisi pengajar atau guru di madrasah-madrasah di Haramayn bukan tanpa alasan, agar diizinkan untuk mengajar, setiap guru diwajibkan mempunyai ijazah (sertifikasi), yang menjelaskan kemampuan (kredensial; surat, sertifikat) akademik pemegangnya.

Kredensial yang terpenting itu adalah isnad, yakni mata rantai otoritas yang menunjukkan hubungan yang tidak terputus antara guru dan murid dalam transmisi kitab-kitab atau ajaran tertentu. Ijazah biasanya dikeluarkan oleh guru kepada muridnya setelah dia belajar dengannya. ${ }^{46}$

\section{Pemikiran Tuan Guru H. M. Said Amin}

Islam merupakan agama yang sangat lengkap dalam mengatur setiap aspek hidup dan kehidupan bagi pemeluknya. Sehingga tidak heran kalau terjadi masalah, maka akan dapat diselesaikan dengan merujuk pada norma-norma dan tata aturan yang telah digariskan dalam Al-Qur`an dan Al-Hadis.

Telah jelas bahwa dalam Al-Qur`an terdapat banyak ayat yang mengandung prinsip-prinsip keagamaan, baik akidah, akhlak, dan prinsip-prinsip hukum yang mengatur perbuatan manusia. Semuanya ini tidak lain dalam rangka membimbing manusia pada kehidupan sebagaimana yang dikehendaki oleh Allah SWT, yakni pada kebaikan dan kebahagiaan.

Sepanjang sejarahnya, pada diri manusia telah berlaku hukum-hukum yang memberikan batasan guna mengatur perbuatanperbuatan individual dan sosial. Hukum-hukum itu bisa berasal dari agama, masyarakat atau yang lainnya. Tanpa ada hukum yang

45 Azyumardi Azra, Jaringan Ulama Timur Tengah dan Kepulauan Nusantara Abad XVII \& XVIII, (Jakarta: Kencana PrenadaMedia Group, 2013), 120.

${ }^{46}$ Azyumardi Azra, Jaringan Ulama, 79. 
mengatur dan mengikat, maka dapat dipastikan bahwa kekacauan dan anarkisme dapat terjadi. ${ }^{47}$

Kesesatan dalam akidah dan ibadahpun dapat terjadi apabila seseorang tidak mengikuti dan meninggalkan salah satu atau kedua warisan yang ditinggalkan oleh Nabi Muhammad SAW, yaitu AlQur`an dan Sunnah Rasulullah. Seringkali dijumpai kaum muslimin yang melaksanakan ibadah tanpa mengetahui landasan dan acuan dalam beribadah. Hal tersebut dapat terjadi karna kurang paham akan ajaran Islam ataupun disebabkan oleh tradisi taklid buta terhadap tradisi yang hidup dan berkembang di tengah kehidupan masyarakat. Padahal dua sumber utama ajaran agama Islam telah menjelaskan segala sesuatu yang berkaitan dengan ibadah dan mu`amalah. ${ }^{48}$

\section{Pandangannya tentang Syari'ah dan Fiqh}

Syari at Islam, sebagaimana yang didefinisikan oleh Tuan Guru H.M. Said Amin dalam bukunya, bahwa Syari at merupakan satu bangunan yang sempurna, dimana semua bagian dari bangunan itu saling menyempurnakan dan menguatkan satu dengan lainnya. Dasar dari bangunan Syari at Islam adalah akidah dan akhlak, tiangtiangnya adalah ibadah dan syi ar, tembok dan sudutnya adalah semua perintah, larangan dan petunjuk yang meliputi semua bagian dari bangunan syariat tersebut, dan semua bagian tersebut tidak dapat dipisahkan satu dengan lainnya. ${ }^{49}$

Kemudian beliau membagi hukum Islam/Syari`at menjadi empat bagian:

1. Seperempat urusan ibadah

2. Seperempat urusan muamalat

3. Seperempat urusan pernikahan

4. Seperempat urusan pidana/kriminal ${ }^{50}$

Cara dan pentahapan penerapan Syari at Islam, baik secara pribadi maupun kolektif, harus dimulai dengan pengenalan tentang hubungan antara manusia dan Syariat Islam, yang beliau umpamakan dengan hubungan antara tanah yang subur atau baik dengan bibit yang

${ }^{47}$ Umar Shihab, kapita Selekta Mozaik Islam, (Bandung: Mizan, 2014), 291.

${ }^{48}$ Said Amin, Ar-Risalah Al-Aminiyah: seri Pengantar Ilmu Fiqh dan Ilmu Hadis, (Bima: IT Press STIS Al-Ittihad Bima, 2013), 1.

${ }^{49}$ Said Amin, Menuju Pelaksanaan Syariat Islam, (Bima: Sehati Press, 2002), 14.

${ }^{50}$ Said Amin, Menuju Pelaksanaan, 4. 
baik dan unggul, selebihnya adalah tergantung pada unsur-unsur pendukung dan penunjang. Beliau mengiyaskan tanah yang baik atau subur sebagai manusia dalam keseluruhan anggota tubuhnya terutama hati nuraninya, sedangkan bibit yang baik atau unggul diumpamakan sebagai Syari at Islam secara kaafah. Jika bibit yang baik itu ditanam dalam tanah yang baik dan dirawat dengan perawatan yang baik pula, maka sudah pasti menumbuhkan tumbuhan yang baik. Tumbuhan yang baik itulah yang selanjutnya menjadi manusia paripurna yang akan membina peradaban manusia yang akan menyejahterakan kehidupan manusia secara kaafah dunia dan akhirat. ${ }^{51}$

Sedangkan Fiqh, secara bahasa berarti al-Fahm ad-Daqiq atau hasil dari pengetahuan yang banyak dan luas ketelitian dan ketajaman di dalam memahami permasalahan di dalam isi kandungan nash yang menjadi dasar dari sumber hukum. Menurut istilah, fiqh adalah hukum yang berhubungan dengan amal perbuatan orang-orang dewasa atau mukallaf yang dikeluarkan atau diistinbathkan dari dalildalil sumber hukum syara ${ }^{52}$

Berdasarkan pengertian di atas tentang makna syari'at dan fiqh seperti yang dikemukakan, maka dapat ditarik suatu kesimpulan bahwa fiqh adalah hasil pemahaman mujtahid terhadap hukum Allah yang diwahyukan kepada Muhammad sebagai Rasul-Nya. Dengan demikian, hukum Allah yang bersifat qath'i, tidak disebut sebagai fiqh tetapi syari'at. Jadi, beliau membedakan antara Syari`at dan fiqh.

\section{Pandangannya terhadap Sumber Hukum Islam}

Tuan Guru H.M. Said Amin dalam bukunya Ar-Risalah AlAminiyah: seri Pengantar Ilmu Fiqh dan Ilmu Hadis, membagi sumber hukum Islam menjadi dua, yaitu Al-Qur`an dan As-Sunnah. Al-Qur`an menurutnya adalah firman Allah SWT yang diturunkan kepada Nabi Muhammad SAW. dengan bahasa atau lafaz Arab yang disampaikan dengan cara yang mutawatir (terjamin kebenarannya) dan membacanya menjadi ibadah bagi pembacanya. ${ }^{53}$ Lanjutnya, bahwa orang yang paling berhak dan benar untuk menjelaskan isi AlQur`an kepada umat manusia adalah Nabi Muhammad SAW. sendiri berdasarkan firman Allah dalam Al-Qur`an surat An-Nahl ayat 43-44.

Adapun semua keterangan dan penjelasan Rasulullah kepada umat tentang mukjizat para Nabi dan isi kandungan al-Qur`an dan

\footnotetext{
${ }^{51}$ Said Amin, Menuju Pelaksanaan, .............., 4-6.

${ }^{52}$ Said Amin, Ar-Risalah Al-Aminiyah: seri Pengantar Ilmu ......., 29.

${ }^{53}$ Said Amin, Ar-Risalah Al-Aminiyah: seri Pengantar Ilmu.........., 5.
} 
kitab-kitab Allah kepada para Nabi dan Rasul utusan Allah kepada umat sebelumnya adalah Sunnah Rasul yang oleh Nabi sendiri dikatakan sebagai Sunnati, sebagaimana keterangan dalam beberapa hadis Nabi. Beliau sepakat dengan ulama hadis yang membagi Sunnah menjadi lima macam, yaitu:

1. Sunnah qauliyah atau ucapan/perkataan nabi yang makna dan lafaz atau redaksinya langsung dari Nabi sendiri.

2. Sunnah fi liyah atau perbuatan Nabi yang maknanya dari Nabi sedangkan lafaznya dari sahabat yang melihat perbuatan Nabi.

3. Sunnah taqririyah atau pengakuan Nabi, yaitu perkataan dan perbuatan sahabat yang didengar atau dilihat atau diketahui oleh Nabi untuk kemudian beliau menetapkan benar atau salahnya.

4. Sunnah hammiyah atau keinginan Nabi yang belum dilakukannya sampai beliau wafat.

5. Sunnah khalqiyah dan khulukiyah atau sifat jasmaniah dan sifat perilaku atau akhlak Nabi. ${ }^{54}$

Kemudian lanjutnya, bahwa semua sunnah ini adalah diucapkan atau dikerjakan atau diikrarkan oleh Nabi hanyalah merupakan pancaran dari wahyu Allah SWT., hal ini sesuai dengan firman Allah dalam surat an-Najm ayat 1-5.

\section{Pandangannya terhadap Sunnah dan Bid`ah}

Menurutnya, mengerjakan sesuatu perbuatan yang tidak diperintahkan atau tidak dikerjakan oleh Nabi, akan tetapi ada dasar atau petunjuk dari salah satu sumber hukum Islam, maka perbuatan tersebut adalah sunnah, bukan bid'ah dalam pengertian syara'. Akan tetapi, apabila mengerjakan sesuatu perbuatan yang tidak diperintahkan atau tidak dikerjakan oleh Nabi atau tidak ada dasar atau petunjuk dari salah satu sumber hukum yang telah disepakati dalam Islam, maka perbuatan tersebut adalah bid ah dhalalah. ${ }^{55}$

Sebagai contoh, mengerjakan do`a bersama imam dengan makmum setelah selesai shalat berjamaah, imam berdoa dan makmum mengaminkan doa imam dengan mengangkat tangan. Sebagian orang berpendapat bahwa perbuatan tersebut adalah bid ah karena tidak pernah dikerjakan oleh Nabi dan sahabat pada masa hidup Nabi.

\footnotetext{
${ }^{54}$ Said Amin, Ar-Risalah Al-Aminiyah: seri Pengantar Ilmu ......, 8.

${ }^{55}$ Said Amin, Ar-Risalah Al-Aminiyah: seri Pengantar Ilmu ........, 42.
} 
Beliau berpendapat bahwa sekalipun perbuatan doa bersama imam dan makmum setelah selesai shalat berjamaah, seperti yang dikatakan tidak dikerjakan oleh Nabi, namun kita melihat beberapa hadis Nabi yang berhubungan dengan perbuatan itu, maka perbuatan tersebut bukanlah bid`ah, dengan dasar beberapa hadis Nabi, seperti hadis Nabi yang diriwayatkan oleh al-Hakim dari Habib bin Salamah al-Fihri, Nabi bersabda: tidaklah berkumpul sekelompok orang, lalu ada di antara mereka yang berdoa dan yang lainnya mengaminkan doanya melainkan diterima oleh Allah doanya. (HR. Al-Hakim, dalam Kitab Targhib wa Tarhib, juz 1: 331 ${ }^{56}$

\section{Pandangannya tentang Jumlah Raka`at Shalat Tarawih}

Dalam bukunya beliau mengatakan bahwa Nabi Muhammad melakukan shalat tarawih yang diikuti oleh para sahabat di Masjid Nabawi hanya tiga malam, sebagaimana keterangan dalam hadis yang diriwayatkan oleh imam Bukhari dari Aisyah. Namun tidak ada ketentuan bilangan rakaat yang pasti untuk shalat tarawih pada zaman Nabi dan zaman khalifah Abubakar. Nabi hanya menentukan waktunya saja yaitu pada setiap bulan Ramadhan yang dimulai setelah selesai shalat sunat Isya sampai terbit fajar, boleh dikerjakan sampai sepertiga malam, setengah malam dan boleh juga satu malam penuh, boleh dilakukan secara berjamaah dan boleh sendiri-sendiri, boleh di masjid ataupun di rumah masing-masing. ${ }^{57}$

Terkait dengan shalat tarawih dan jumlah rakaatnya, beliau memberikan catatan-catatan sebagai berikut:

1. Shalat tarawih pada masa rasulullah dan masa Abubakar, tidak ada ketentuan rakaat yang pasti dan tidak pula terdapat satu hadis shahih pun yang menjelaskan demikian dari Rasulullah.

2. Nabi tidak mencontohkan bilangan rakaat tertentu bagi shalat tarawih, tetapi hanya mencontohkan lama waktunya yaitu sepertiga, setengah atau semalam penuh.

3. Bilangan rakaat terserah pada kemampuan orang yang melaksanakan shalat, tentang lama dan singkatnya berdiri membaca ayat pada setiap rakaat dalam memenuhi waktu sepertiga malam, setengah malam dan satu malam itu.

${ }^{56}$ Said Amin, Ar-Risalah Al-Aminiyah: seri Pengantar Ilmu Fiqh

43. Lihat juga Said Amin, Sifat Shalat Rasulullah, (Surabaya: Sunan Ampel Press, 2012), 162 2012), 78-83.

${ }^{57}$ Said Amin, Sifat Shalat Rasulullah, (Surabaya: Sunan Ampel Press, 
4. Umar bin Khattab mengerjakan shalat tarawih 20 rakaat dan witir 3 rakaat, dengan 2 rakaat sekali salam dengan membaca ayat yang tidak Panjang.

5. Cara Umar tersebut disetujui dan diikuti oleh semua sahabat termasuk Aisyah dan tidak ada seorangpun yang menentangnya. Oleh karena itu, telah terjadi ijma sahabat.

6. Cara seperti itu pula yang dilaksanakan oleh para ulama tabi in dan ulama fiqh, khususnya imam mzhab yang empat.

7. Ijma` ulama terutama ijma` sahabat menjadi salah satu sumber hukum Islam yang harus diikuti oleh umat Islam.

8. Mengikuti cara para sahabat khufaurrasyidin adalah mengikuti perintah Nabi.

9. Shalat yang sebelas rakaat atau tiga belas rakaat yang biasa dikerjakan oleh Nabi pada setiap malam tersebut adalah shalat witir atau shalat lail (tahajjud) dan ditutup dengan witir satu rakaat. ${ }^{58}$

\section{Pandangannya tentang Posisi kedua Tangan dalam Shalat}

Memahami isi kandungan hadis Nabi dan pendapat para mujtahidin serta jumhur ulama, tentang posisi kedua tangan di dalam shalat, beliau memberikan catatan dan penegasan dalam bukunya:

1. Waktu berdiri mengucapkan takbiratul ihram, mengangkat kedua telapak tangan sejajar dengan kedua bahu, anak-anak jari tangan sejajar dengan kedua telinga dan ibu jari tangan berada di bawah daun telinga.

2. Waktu berdiri membaca doa iftitah, membaca fatihah dan ayat lain, disunnahkan untuk memegang telapak tangan, pergelangan dan lengan tangan kiri dan keduanya diletakkan di bawah dada dan di atas pusat.

3. Disunnahkan juga pada waktu bangun dari ruku` kedua belah tangan diangkat sejajar dengan bahu dan telinga dan diturunkan kembali sambil turun untuk sujud (tidak bersedekap waktu i'tidal).

4. Waktu tasyahud akhir, anak-anak jari tangan kanan, jari manis dan kelingking digenggamkan, jari tangan dan ibu jari membentuk lingkaran dan jari telunjuk dinaikkan pada saat

${ }^{58}$ Said Amin, Sifat Shalat $131-133$ 
mengucapkan Allah (lafzul jalalah) dan tidak mengerakgerakkan berulang-ulang sampai salam. ${ }^{59}$

\section{Pandangannya tentang Sistem Pemerintahan}

Menurutnya, untuk tegaknya system politik Islam itu harus berdiri di atas 3 pilar yang besar dan kuat, yaitu:

1. Legalitas atau legitimasi Islam atau Syari ah Islamiyah yang menaunginya

2. Umat Islam yang melaksanakannya

3. Kekuasaan Islam yang melindunginya

Lanjutnya, apabila kekuasaan atau pemerintah sudah berdiri tegak atas dasar Syari at Islam dan keridhaan serta persetujuan umat Islam, maka masalah bentuk pemerintahan tidak menjadi masalah penting dan prinsipil, artinya kekuasaan atau pemerintahan itu dapat berbentuk kerajaan, khilafah, imamah, imarah, kesultanan, republik dan lain-lain, dan pemimpinnya boleh digunakan dengan nama raja, sultan, amir, imam, presiden dan lain-lain, yang terpenting adalah kaitannya dengan proses pengangkatan dan pemilihannya telah memenuhi dua persyaratan pokok prinsipil, yaitu melalui ketentuan syari at dan keridhoan atau persatuan umat Islam. Akan tetapi, jika salah satu persyaratan tersebut tidak dilaksanakan, maka gugurlah keabsahan atau legitimasi dari pemerintahan tersebut. ${ }^{60}$

\section{Kesimpulan}

Kebijakan Kesultanan Bima dalam bidang Pendidikan keislaman adalah memberikan kesempatan dan fasilitas bagi masyarakatnya yang berniat menuntut ilmu keislaman di Timur Tengah, yang kemudian diharapkan akan menjadi transmitter utama dalam tradisi intelektual keagamaan dan sosio-moral di Bima.

Bima merupakan simpul utama dalam jejaring ulama di Timur Nusantara yang terhubung dalam jaringan ulama di Jawa dan Haramayn. Peranan ulama Bima di Haramayn sangat krusial dalam jaringan ulama Nusantara di Timur Tengah, sebagaimana yang diperankan oleh Syekh Abdul Ghani Al-Bimawi, yang mengantarkannya pada tingkatan tertinggi sebagai seorang Ulama dan Mahaguru bagi ulama-ulama di Nusantara pada abad XVIII- XIX.

\footnotetext{
${ }^{59}$ Said Amin, Sifat Shalat..................., 46-47.

${ }^{60}$ Said Amin, Menuju Pelaksanaan, ............., 79.
} 
Dilihat dari latar Pendidikan, ketokohan, mata rantai intelektualitasnya, pemikiran dan karya intelektualnya serta kontribusinya terhadap perkembangan keislaman di Bima, maka tidaklah berlebihan kalau Tuan Guru H.M. Said Amin, dikatakan sebagai pelanjut sanad keilmuan dalam jaringan ulama Nusantara yang berasal dari Bima pada abad ke-XX. Sehingga didapati bahwa karakteristik pemikiran fiqhnya memerlihatkan warna Syafi`iyah yang kental. Pada sisi lain, internalisasi dan pergulatannya dengan kelompok Islam modernis turut mewarnai keunikan pemikirannya, yang merupakan kombinasi antara tradisionalisme dan modernisme. 


\section{DAFTAR PUSTAKA}

Amin, TG. H.M. Said, Sifat Shalat Rasulullah, Surabaya: Sunan Ampel Press, 2012.

Ar-Risalah Al-Aminiyah, seri Pengantar Ilmu Fiqh dan Ilmu Hadis, Bima: IT Press STIS Al-Ittihad Bima, 2013. , Ar-Risalah Al-Aminiyah, seri Aliran-aliran Ilmu Kalam, Bima: IT Press STIS Al-Ittihad Bima, 2014. , Ar-Risalah Al-Aminiyah, seri Manusia dan Ibadah Haji, Bima: IT Press STIS Al-Ittihad Bima, 2013. , Ar-Risalah Al-Aminiyah, seri Perjalanan Hidup Manusia dari Alam Arwah sampai Alam Baqa, Bima: IT Press STIS Al-Ittihad Bima, 2014. , Ar-Risalah Al-Aminiyah, seri Siksa dan Nikmat Kubur, Bima: IT Press STIS Al-Ittihad Bima, 2014. ., Menuju Pelaksanaan Syari`at Islam, Bima: Sehati Press, 2002.

Aizid, Rizem, Biografi Ulama Nusantara, Yogyakarta: Diva Press, 2016.

Abdullah, T. Karim, Metodologi Penelitian Agama: Sebuah Pengantar, Yogyakarta: Tiara Wacana, 1989.

Anwar M. Khoiril, Peran Ulama di Nusantara dalam Mewujudkan Harmonisasi Umat Beragama, dalam Jurnal Fikrah, vol. 4 Nomor 1, tahun 2016.

Azra, Azyumardi, Jaringan Ulama Timur Tengah dan Kepulauan Nusantara Abad XVII \& XVIII, Jakarta: Kencana PrenadaMedia Group, 2013.

Bizawie Zainul Milal, Masterpiece Islam Nusantara: sanad dan jejaring ulama-santri (1830-1945), Jakarta: Pustaka Compass, 2016.

, Zainul Milal, Syekh Mutamakkin: Perlawanan Kultural Agama Rakyat, Ciputat: Pustaka Compass, 2014.

Dhofier, Zamakhsyari, Tradisi Pesantren, Jakarta: LP3ES, 2011.

Fadli, Adi, Pemikiran Islam Lokal: Studi Pemikiran TGH. M. Soleh Chambali Bengkel Al-Ampenani, Yogyakarta: UIN Sunan Kalijaga, 2010.

Huda, Nor, Islam Nusantara: Sejarah Sosial Intelektual Islam di Indonesia, Yogyakarta: ar-Ruzz Media, 2013. 
Iswanto, Agus, Sejarah intelektual Ulama Nusantara: Reformulasi Tradisi di Tengah Perubahan, dalam Jurnal Lektur keagamaan, Vol. 11, No. 2 tahun 2013

Jamaluddin, Keterlibatan Ulama Sasak dalam Jaringan Ulama periode 1754-1904, dalam Jurnal al-Qalam, vol 22 Nomor 1 juni 2016.

Moeloeng, Lexy J., Metodologi Penelitian Kualitatif, Bandung: Rosdakarya, 2012, edisi revisi.

Suprayogo, Imam dan Tobroni, Metodologi Penelitian Sosial-Agama, Bandung: Rosdakarya, 2001.

Ulum, Amirul, Syaikh Nawawi Al-Bantani, Yogyakarta: Global Press, 2016.

Ulum, Amirul, Syaikh Yasin Ibn Isa Al-Fadani, Sang Musnid Dunya dari Nusantara, Yogyakarta: Global Press, 2016.

Zuhri, Achmad Muhibbin, Pemikiran K.H.M. Hasyim Asy`ari tentang Ahl al-Sunnah wa al-jama`ah, Surabaya: Khalista, 2010. 